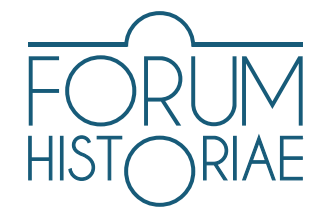

\title{
On Football Fanzines: A Communication Platform for Czech and Other European Football Fans ${ }^{*}$
}

\author{
Jan Lomíček
}

\begin{abstract}
LOMÍČEK, Jan: On Football Fanzines: A Communication Platform for Czech and Other European Football Fans.

The aim of this paper is a description of domestic football fanzine production in comparison with developments abroad. Zines from the scenes of football fans represent a key source for mapping their histories. While fanzine production is not a new topic in international critical literature, in the Czech Republic it has received only limited attention. The majority of football fanzines in the Czech Republic arose in the milieus of specific subcultural groups - football hooligans and ultras. From 1998 to 2008 the nationwide title Football Factory was the key zine surveying the scene, and it provided a kind of general communication platform for Czech football fans. In terms of their direct impact, Czech football fanzines were the products of a limited scene and a limited trend. As such, they remained quite marginal from the standpoint of overall Czech fanzine production.
\end{abstract}

Keywords: football fanzines; Czech Republic; football subcultures; football fans; hooligans; football ultras; Football Factory

DOI: https://doi.org/10.31577/forhist.2020.14.1.9

$F_{t}$ anzines are generally a key source for mapping the milieus of subcultures, i.e. the parallel or alternative networks that operate in relation to the majority of society or the mainstream. Zines from the scenes of collective sports fans are an integral part of this category. In this context, football fans have a central role. ${ }^{1}$ Although active fan groups have formed around other sports, thanks to its mass appeal and almost global spread, football has been a highly specific phenomenon since the 19 th century, with popularity spanning social classes and nations. As observers of the unfolding of the "great" history of an individual team, its highs and lows, internal club dynamics and the microhistories of individual matches, football fan groups have a collective memory and thus they share a wide-ranging history. This history is also shaped by the social dynamics of the conflict between the fan group and one or more opposing groups - whether this is in an official sports context when cheering for their team or in the illicit and often violent clashes that

\footnotetext{
* This article was created as part of the research supported by Project GA ČR no. 17-09539S Budování scény: česká a slovenská kultura fanzinů od státního socialismu k post-socialismu / Building up the Scene: Czech and Slovak Fanzine Culture from State Socialism to Post-Socialism.

1 Zines from sports-related scenes are included in Stephen Duncombe's taxonomy of zines of different subcultures. See DUNCOMBE, Stephen. Notes from Underground: Zines and the Politics of Alternative Culture. Bloomington; Portland : Microcosm Publishing, 2008, p. 15. Several other authors have also drawn attention to these zines, particularly as a source about specific football-related subcultures. See JARY, David - HORNE, John - BUCKE, Tom. Football Fanzines and Football Culture: a Case of Successful Cultural Contestation. In Sociological Review, 1991, Vol. 39, No. 3, pp. 581-597; MILLWARD, Peter. The Rebirth of the Football Fanzine. In Journal of Sport and Social Issues, 2008, Vol. 32, No. 3, pp. 299-310.
} 
take place in the stadium stands and beyond. The vast majority of football fans never take part in football-related violence. There are few, however, who haven't heard of it or encountered it - if only from a distance in the stadium or elsewhere.

One of the most significant sources which preserve semi-official fan histories and, thus, a view of the activities of the subcultures associated with football - is football fanzines that come out of these scenes. This study begins with a brief historical survey of these fan scenes and then highlights current knowledge about the zines created within football fan communities both in the Czech Republic and abroad. The first football fanzines originated in the cradle of the game, the United Kingdom. Since then, the fanzine phenomenon has spread across Europe. This, however, has been subject to local peculiarities often related to the fragmentation of individual national football scenes. In the Czech Republic, the majority of football fanzines arose in the milieus of specific subcultural groups - football hooligans and ultras. From 1998 to 2008, Football Factory was the key zine surveying the scene, and it provided a kind of general communication platform. In particular, this zine became a mediator of behind-the-scenes developments and clashes between football hooligan groups both inside and outside the stadium. It also served as an information source about the unofficial goings-on in football stadiums more generally.

This study is based on an analysis of secondary literature about football fanzines along with primary sources, i.e. football fanzines available on the Czech scene. The original series of Football Factory (60 issues published between 1998 and 2008) is its key source. Given the scope of this study, I have adopted a descriptive approach, since quantitative methods would have been too time-consuming. Thus, my central research task is a description of domestic football fanzine production in comparison with developments abroad. While fanzine production is not a new topic in international critical literature, in the Czech Republic it has received only limited attention.

\section{Football and Fan Subculture Scenes}

In the context of historiography, interest in the history of the sport as a social and athletic phenomenon is well-established, and the same is true of more or less active sports fans. Outside the Czech Republic, and in the English-speaking world especially, several critical publications and studies have emerged on these subjects. These include a number of critical journals dealing with sports games and related issues. The sport appears in several works by significant figures in modern sociology, who either address sport itself as a sociological phenomenon or examine it as a social field, including an assessment of particular social class preferences. ${ }^{2}$ Football, generally the most popular sport, has been studied similarly. In terms of international and Czech historiography, many collective

2 BOURDIEU, Pierre. Sport and Social Class. In Social Science Information, 1978, Vol. 17, No. 6, pp. 819-840; ELIAS, Norbert - DUNNING, Eric. Quest for Excitement: Sport and Leisure in the Civilizing Process. Oxford : Blackwell, 1986. Examples of critical periodicals include The International Review for the Sociology of Sport (IRSS) and Sociology od Sport Journal (SSJ). 
and local football histories have been compiled. Up until the early 1990s, these works mainly took the form of chronicles or memoirs; ${ }^{3}$ however, at the beginning of the 1990s and under the influence of trends in the West, the Czech research field expanded. With this expansion of the methodological framework, the social sciences began to take on new topics. These included different social groups and subculture scenes and, again in response to developments in the West, attention gradually turned to sports fans. Many works appeared about the organisation, characteristics, age distribution and social status of sports fans. ${ }^{4}$ Very often, these studies concerned fans on the fringes of the mainstream, i.e. groups whose behaviour was - to the general public - outlandish or even extreme.

Based on fans in the so-called "Kops" and their activities during and after matches, ${ }^{5}$ we can briefly highlight some key phenomena about fan groups. The number of these groups and the spread of fandom itself can be broadly attributed to the relative surge in football's popularity since the second half of the 19th century as well as its subsequent professionalisation, commercialisation and media coverage. At the same time, there has been a rise in the more negative phenomena associated with the football scene. Therefore, in the late 1990s popular studies focused on corruption in the world of football and violence around the game. ${ }^{6}$ Critical surveys of the milieus of football fans concentrated on the subculture scenes of so-called hooligans. In the former Eastern bloc countries, social scientists sought to map the development of radical football fandom, driven mainly by a shift in local football-related violence after 1989: unorganised brawls turned to pre-arranged showdowns between football hooligan gangs. A report on the negative impact of hardcore fans, which attempted to survey the problem and propose solutions for better control by mainstream society, appeared in the then Czech and Slovak Federative Republic as early as $1991 .^{7}$

Critical publications about football fans divide the people watching the game into three or four basic groups: football spectators, football fans, football hooligans and a somewhat ill-defined group called "ultras" ${ }^{8}$ From a general historical standpoint,

3 For Czech football histories, see ŠÁLEK, Zdeněk. Slavné nohy: Českoslovenští fotbaloví reprezentanti. Praha : Práce, 1980; Svět devadesáti minut: $z$ dějin československé kopané, 1-2. Praha : Olympia, 1976, 1981; VANĚK, Karel, (ed.) Malá encyklopedie fotbalu. Praha : Olympia, 1984.

4 SEKOT, Aleš. Sociologie sportu. Brno : Masarykova univerzita, 2006; SLEPIČKA, Pavel et al. Divácká reflexe sportu. Praha : Karolinum, 2010; CHARVÁT, Michal. Hostilita ve sportovním prostředí. Brno : BMS creative, 2008.

5 The phrase "the Kops" originally referred to the place in the stadium (mostly behind the goals) where radical fans met up and later became a synonym for the entire radical fan base of a particular team. In current research, the term "radical fan" is used mainly to describe the fandom of so-called hooligans and ultras. In many cases, the extremity of these groups lies not in their cheering or violence but in their political ideologies. 6 FELT, Karel - JEŽEK, Ladislav. Fotbal plný hříchů. Praha : Cesty, 1995.

7 VEČERKA, Kazimír (ed.) Jak na fotbalové výtržníky: zpráva o průzkumu negativních projevů vlajkonošu a možností jejich prevence. Praha : Institut pro kriminologii a sociální prevenci, 1991; MAREŠ, Miroslav SMOLÍK, Josef - SUCHÁNEK, Marek. Fotbaloví chuligáni: evropská dimenze subkultury. Brno: Centrum strategických studií, 2004; SMOLÍK, Josef. Fotbalové chuligánství: historie, teorie a politizace fenoménu. 1. vyd. Karlovy Vary : Zdeněk Plachý, 2008; KASAL, Josef. Násilí na stadionech jako odraz kultury. Hradec Králové : Gaudeamus, 2013.

8 MAREŠ, Miroslav - SMOLÍK, Josef - SUCHÁNEK, Marek. Fotbaloví chuligáni: evropská dimenze subkultury. Brno : Centrum strategických studií, 2004, pp. 10-14, 30-31. Similar and more detailed categories are described elsewhere: see, e.g. SCHOLZ, Petr. Problematika fotbalového diváctví v České republice, aneb „Quo vaditis, fotbaloví př́znivci?". Brno : Paido, 2018, pp. 41-56. 
it was primarily identification with particular sports clubs that led to the formation of the football fan scene. This often went hand in hand with identification with the local, national, religious or political affiliations of the club as well as (self-) definitions in opposition to its rivals (and later perhaps also to more "amateur" spectators). Other phenomena were also at work here, such as the occupation of public space - whether this was at home or on an opponent's turf - through the symbolism associated with the parent club. These symbols included club colours on flags or clothing accessories, club chants and later elaborate choreographies, pyrotechnics, graffiti and other elements that were adapted quite flexibly to broader social trends and developments. The forms of occupation of public spaces and clashes - both actual and symbolic- with rival groups also depended on the personal behaviour of the fans/supporters of particular clubs, which differed across groups, i.e. fans, hooligans and ultras.

The different characteristics of the individual fan groups were listed by Mareš, Smolík and Suchánek. ${ }^{9}$ These scholars note that, among other things, the football spectator group shows low levels of stability, integration, guiding values, nationalism, xenophobia and racism, control, clubism and violence but a high degree of permeability (openness to new members) and a large population size. In contrast to the spectators, the group of common fans (slang: "the normals") shows high stability and integration of the group, medium value orientation, high manifestations of nationalism, exceptional manifestations of xenophobia and racism, a medium degree of control, a high degree of clubism, a low level of violent behaviour, medium permeability and medium quantity. The football hooligans group then shows a high degree of stability, integration and value orientation, high manifestations of nationalism, frequent manifestations of xenophobia and racism and a high degree of control and violent behaviour; however, its permeability (possibility of joining the group), abundance and clubism are low. In the case of ultras, the definition of the group remains somewhat ambiguous, since the behaviour of members oscillates between that of fans and hooligans with differences in each European national football scene. Ultras express themselves mainly through intensified displays of club affiliation and through the occupation of public space in stadiums using sophisticated means such as choreo (organised fan choreography), flags, stickers and graffiti. ${ }^{10}$

Although violence around larger public sports events has been a problem since antiquity, and some scholars trace its origins to medieval collective games, or rather their bloody side effects, the birth of modern sports fandom, with all its negative consequences, is tied to the development of modern sports and broader social transformation during the 20th century. Apart from changes in leisure time, this includes the emergence of brand new subcultures and associated moral panics in mainstream society - often caused by the exaggerated images of subculture members conveyed by the media. Ever since football became a phenomenon, 
violent clashes among fans both during and outside matches have attracted media interest. Historical research shows that in the UK, the birthplace of modern football, these incidents were not uncommon from the early days of the game. Violence between football fan groups has been on the rise in the UK since the 1960s. It was then that youth subculture members began to be seen in the stands and elsewhere and were condemned by the media as violators of public order and perpetrators of football-related violence. An initial focus on Teddy Boys, members of the British subculture of rock and roll fans, switched to Mods and Rockers, who were, in turn, replaced in the stands by members of the emerging skinhead subculture. Football hooligans would eventually discover one disadvantage of skinhead style - its easy identification by authorities - and change their look to that of "casuals". This was, however, some years away. ${ }^{11}$

The interest of social scientists in negative social developments around radical fan groups has grown proportionally with the rise in football fan violence since the 1970s and 1980s. It was during these decades that this violence - partly associated with the activities of British hooligans or "rowdies" at home and abroad - became a Europe-wide problem. In the 1970s, the phenomenon was selected as a topic for subculture research at the Centre for Contemporary Cultural Studies at the University of Birmingham. At first, these scholars focused on members of subculture groups (rockers, mods and skinheads) in the stands, but later their interest turned to football audiences more generally.

While there had been eruptions of English football hooliganism abroad in European football cups since the 1970s, the catastrophe at Heysel Stadium in Brussels in 1985 marked a symbolic crisis point. During the finals of the European Champion Clubs' Cup (the predecessor of the current UEFA Champions League) that year, 39 Juventus Turin fans were trampled to death and several hundred people were injured in the panic caused by the actions of a radical core of FC Liverpool fans. On the one hand, insufficient security and organisation and the less-than-satisfactory state of the stadium created the conditions for the disaster. On the other, old grievances played their role: in the cup finals between FC Liverpool and AS Roma one year earlier, there had been many match-related incidents between Italian and English fans, leaving several people injured. ${ }^{12}$ After the 1985 events, television footage and photos from Brussels quickly spread around the world. The public was appalled and the mainstream media began to focus on the football hooliganism issue..$^{13}$ Campaigns by European authorities

11 MURPHY, Patrick. Football on Trial: Spectator Violence and Developments in the Football World. London : Routledge, 1990.

12 Krátce z domova i z ciziny. In Rudé právo, 1. June 1985, p. 8.

13 In the Czechoslovak context, the official daily Rudé právo responded to the tragedy by giving a brief history of football-related violence in the United Kingdom. Among its list of past hooligan brawls and the numbers of injured up until 1985, the paper included a tragic accident at a Glasgow stadium in 1971 in which 66 spectators were crushed to death and more than 200 were injured. That disaster had no connection with hooliganism. See Ohlasy na tragédii na bruselském stadionu. Nejhorší demonstrace fotbalového chuligánství. In Rudé právo, 31. May 1985, p. 8. Another report highlighted earlier incidents involving English fans during their trips abroad. See FELT, Karel - KUBÍN, Miroslav. Tragédie nad rámec sportu. In Rudé právo, 1. June 1985, p. 8 . 
(resulting in the European Convention on Spectator Violence ${ }^{14}$ ) and the Thatcher government in the UK against football violence inside and outside the stadium ${ }^{15}$ led to Europe-wide initiatives against hooligan groups.

In the 1980s, phenomena like fans' occupation of public spaces and (still unorganised) violence during football matches spread even behind the seemingly impenetrable Iron Curtain into socialist Czechoslovakia. In keeping with the Western media message, they were described as symptoms of the "British disease". ${ }^{16}$ As photos from the period suggest, many Czechoslovak fans within the emerging ultras did not even try to conceal their British inspiration. Although there had likely been some incidents as early as in the late 1970s, the media paid little attention to them. The best-known event, which journalists linked to the Brussels tragedy, was an infamous trip made by Sparta Prague fans to Bánská Bystrica during which they damaged the Slovakia-bound train they travelled in. The incident occurred in June 1985, shortly after the Brussels disaster, and consequently attracted much publicity. ${ }^{17} \mathrm{~A}$ trial of the perpetrators followed, and in 1987 a now classic movie based on these events was released under the title Proč? (Why?). ${ }^{18}$ The media also highlighted the death of an elderly female passer-by, who had been caught up in a clash between Sparta and Pilsen fans at a train station in 1988. Journalists connected the incident to the activities of English hooligans during the world football championship in West Germany the previous June. As the 1980s came to a close, spectator violence thus increasingly became a key focus of both social scientists and criminologists. ${ }^{19}$

Within the Eastern bloc, the Czechoslovak experience - including the initial lack or limited amount of coverage of negative football-related phenomena - was in no way isolated. There was, for instance, no information in the Polish media about the riots during the 1980 Polish cup final between Legia Warsaw and Lech

14 The full title of this legislation was the European Convention on Spectator Violence and Misbehaviour at Sports Events and in particular at Football Matches (1985). It came into effect in November 1985, that is, six months after the Brussels tragedy.

15 The Thatcher government's campaign culminated in the adoption of the UK Football Spectators Act in 1989, which focused on football matches in England and Wales. This statute introduced controls over problematic fans and potentially denied them stadium entrance. A decade later, it was replaced with even stricter legislation under the Football (Disorder) Act (2000).

16 VOLEK, Jiří. Britská nemoc za Husáka. In VLADIMIR 518 et al. Kmeny 0: městské subkultury a nezávislé společenské proudy před rokem 1989. Praha : Bigg Boss \& Yinachi, 2013, pp. 456-487.

17 Rudé právo compared the fans' behaviour to that of English hooligans, and the incident was later condemned by the Union of Friends of Sparta Prague, the official association of club supporters. The club responded by imposing stricter controls on those entering the stadium including bans on the sale of alcoholic beverages and the admission of hardcore fans. See Vandalismus nestrpíme. In Rudé právo, 20. June 1985, p. 8; MIKA, Z. Takoví nemají ve Spartě místo. Ostré odsouzení vandalů. In Rudé právo, 21. June 1985, p. 8; Rozhodná opatření Sparty. In Rudé právo, 22. June 1985, p. 8. The train incident was also mentioned in the official sports daily; see Jízda málo spanilá. Vandalismus v našem sportu nestrpíme In Čs. sport, 20. June 1985, p. 8.

18 Proč?, a film directed by Karel Smyczek based on a script by Radek John, premiered on 1. October 1987. The film was meant to have an educational purpose and highlight problems with youth culture, but it has since become a cult classic among football fans. The same mythic status applies to the incident involving Sparta fans on which the film was based. VOLEK 2013, pp. 456-487.

19 SLEPIČKA, Pavel - PEKÁREK, Jiří. Sportovní diváctví: rozbor negativních jevů na stadiónech: prevence proti diváckým výstřelkům. 1. vyd. Praha : Olympia, 1990; VEČERKA, Kazimír (ed.) Jak na fotbalové výtržníky: zpráva o průzkumu negativních projevů vlajkonošủ a možností jejich prevence. Praha: Institut pro kriminologii a sociální prevenci, 1991. 
Poznań, which caused one death and allegedly several hundred injuries. ${ }^{20}$ Likewise, in 1982, the Soviet media initially downplayed one of the worst spectator tragedies in Soviet history, which took place at Luzhniki Stadium, in which 66 home team fans were crushed to death in the crowd during a UEFA Cup match between Spartak Moscow and HFC Haarlem, the result albeit of an accident rather than spectator violence. ${ }^{21}$ Violent clashes related to football occurred in the Soviet Union as early as the 1980s. Among the most significant were the Kyiv football riots, which broke out during a match between Spartak Moscow and local team Dynamo Kyiv in 1987. This time, however, the violence provoked a considerable media response. ${ }^{22}$

After the societal changes of the late 1980s and early 1990s, the Czech and Slovak radical football fan scenes also saw significant shifts. Newly open borders brought the chance to seek immediate inspiration abroad, both by attending matches and personally connecting with other European scenes. The same exchanges became possible for the members of many other former Eastern bloc scenes, including those in Poland, Hungary and the countries of the former Yugoslavia and the former Soviet Union. ${ }^{23}$ For the radical fan scene in the Czech Republic, the $1990 \mathrm{~s}$ were thus a time of major transformation. New opportunities led to the better organisation of the scene, or rather of its components, the groups around individual clubs. Moreover, new tactics came from abroad that included and went beyond the occupation of stadium space. This meant, at least in some respects, the end of the so-called pre-hooligan era of spontaneous football-related violence, riots and vandalism. Fan activities inside the stadium and elsewhere were gradually taken over by organised groups of football hooligans. ${ }^{24}$

The behaviour of the football hooligans of the 1990s initially focused on attacks on the fans of opposing clubs and unorganised brawls in and outside of stadiums. Later, there was a rise in pre-arranged showdowns with rival hooligan groups. At the same time, social networks developed both domestically and across the border. From the mainstream media's perspective, hooligans were mainly an issue at times of group violence or disturbances which affected the otherwise uninvolved public. The latter included an incident in the first half of the 1990s when two radical fans from Brno threw a soldier from a train, leading to the man's death after his fall. In another controversial case in 1999, a group of Baník hooligans pelted a train carrying Olomouc club fans with stones. The attack injured a young woman, who suffered lifelong consequences, and the perpetrators were given a custodial sentence with no chance of probation.

20 KOSSAKOWSKI, Radoslaw. From Communist Fan Clubs to Professional Hooligans: A History of Polish Fandom as a Social Process. In Sociology of Sport Journal, 2017, Vol. 34, No. 3, p. 284.

21 At the time, this incident was only mentioned briefly in the Moscow daily Vechernaya Moskva. In contrast, there was more coverage in the Western media. The real scope of tragedy was not revealed in the Soviet press until the end of the 1980s.

22 MAREŠ - SMOLÍK - SUCHÁNEK 2004, pp. 118-121.

23 KOSSAKOWSKI, pp. 281-292.

24 MAREŠ - SMOLÍK - SUCHÁNEK 2004, pp. 129-134. 
During the second half of the 1990s and the first decade of the 2000s, the first more tightly organised hooligan groups began to form in the Czech Republic, where the scene had become comparable to those around football rioters abroad. Organised hooligan gangs in the country were thus almost 20 years behind their counterparts in the English-speaking world. This was due on the one hand to the repressive Czechoslovak state apparatus before 1989 and on the other to the relatively limited size of the subculture compared to its equivalents in the United Kingdom and some other European nations. Researchers estimate that around the year 2000, the Czech hooligan scene consisted of 300 to 350 individuals. ${ }^{25} \mathrm{As}$ had been the case in England a few years earlier, members of the skinhead scene gradually began to appear at Czech football matches in the 1990s. Compared to the British subculture, the Czech skinhead scene of the first half of the 1990s was arguably more politicised, and tensions within the group had an impact on the Kops.

The most noticeable hooligan gangs in the Czech Republic formed around clubs with strong fan bases. In addition to the communities associated with the Prague clubs Sparta and Slavia, many groups emerged around Baník Ostrava and FC Brno and some smaller groups formed around other clubs. According to Mareš, Smolík and Suchánek, the first formally named gang was Brigade Drápek z Lasičky (BDzL), created by fans of Sparta Prague in the mid-1990s. In their list of other major hooligan gangs established before 2004, these researchers include the Johny Kentus Gang (JKG) and Orthodox Fans Brno (both associated with 1. FC Brno), Apple Commando and Chachar Boys (both associated with Baník Ostrava), Berserk (Bohemians Prague), Brigate ' 97 and Slavia Hooligans (both associated with Slavia Prague), Red Pirates Prague (Sparta Prague), Pilsen bOi!s (FC Viktoria Pilsen), Divison Nord (Teplice football club), Hovada Zubr and NS Commando (both associated with SK Sigma Olomouc), and Brüx Vandals (FC Baník Most or FC MSU Most 1996 and later FK SIAD Most). Friendships and associations also formed among some of these groups. These links could be temporary and strategic for gangs associated with clubs in the highest league, or more enduring for groups in lower divisions. Some Czech gangs also had ties to hooligan and ultras groups abroad, especially in Slovakia, Poland and Germany. ${ }^{26}$

\section{Football Fanzines}

At the end of the 1980s, football fanzines emerged as a new phenomenon in the Czech Republic as part of the transformation of club fan groups and the surrounding scene. Just a few years later, these zines could no longer be considered a novelty among alternative culture publications in the Czech Republic or internationally. In fact, the earliest fanzines had appeared in the English-speaking world back in the 1930s as a means of communicating across alternative scenes. The form found a new popularity in European alternative scenes in the 1970s, with fanzines

\footnotetext{
25 SMOLÍK 2008, p. 137.
}

26 Examples of domestically linked include Baník Ostrava - Rudá hvězda (Red Star), later FC Union Cheb and FC Brno - Klatovy. Among the Czech-Slovak pairings were FC Brno - Slovan Bratislava and Baník Ostrava -Spartak Trnava. Czech-Polish partnerships included Baník Ostrava - GKS Katowice. See MAREŠ - SMOLÍK SUCHÁNEK 2004, pp. 134, 135-137. 
mainly emerging from British music subculture communities, especially punk. The UK punk zines Sniffin'Glue and Ripped and Torn were early titles in the new wave of amateur do-it-yourself journalism that began in 1976. ${ }^{27}$

In many subculture scenes, zines served as the main communication platform essentially until the mass penetration of the Internet, and the zine journalism that came out of the UK alternative communities in the 1970s marked a turning point. Zines gave the subculture a communication forum while also recording its history and creating a network of readers (and contributors/content creators). One by one, punk, oi!, ska and metal fan groups and the members of other parallel UK scenes started their own zines. For British football fans, the situation was no different, and the first fanzine titles soon began to appear, produced either by fan groups of particular clubs or established publications wanting a wider impact.

British football zine-makers drew inspiration from the national punk zine scene. While there were a number of predecessors, the real boom in football publications occurred in the 1980s. In the context of British fanzine culture, it is noteworthy that one of the first recognised national football zines, When Saturday Comes, debuted in 1986 as a supplement of the music fanzine Snipe! The first British football fanzine, sometimes called a "pre-fanzine", was probably the satirical zine Foul! published between 1972 and 1976 by University of Cambridge graduates. It imitated the style of the British satirical magazine Private Eye and mainstream football publications like Shoot! and Goal and anticipated some of the design features of subsequent music fanzines. In a way, Foul! became a prototype for a certain kind of British football zine. ${ }^{28}$ Meanwhile, the first club-related zines appeared in the mid-1970s in York, Bradford and London. Early football fanzines of the 1980s included Terrace Talk, which came out of the York City FC ultra and hooligan scene in 1981. It served as a template for publishers of independent football print media throughout the 1980s.

The 1980s saw the significant development of zine journalism among British football fans. Football zines of the time became an important communication hub for fan groups given the attitude of the mainstream UK media, which was creating a moral panic in response to growing issues with football hooligan gangs and several tragedies (the Bradford Stadium fire and European cup final disaster in Brussels, both in 1985, and the Hillsborough Stadium catastrophe in 1989). Mainstream coverage of football and its spectators in the 1980s was thus decidedly one-sided. Against this backdrop, the rise of British football fanzines was part of an effort to show an image of football match attendees that was closer to the reality. At the same time, it reflected the increasing activism of fans, who sought to defend themselves against the technocratic rules imposed by British authorities in

27 According to Duncombe, the first of these publications was the punk zine Punk, which appeared in New York in January 1976. DUNCOMBE 2008, pp. 113-132.

28 For a discussion of Foul! and the surrounding UK scene, see, for example, SHAW, Phil. Whose Game Is It Anyway?: The Book of Football Fanzines. Hemel Hempstead: Argus, 1989, pp. 6-16; JARY, David - HORNE, John - BUCKE, Tom. Football Fanzines and Football Culture: A Case of Successful Cultural Contestation. In Sociological Review, 1991, Vol. 39, No. 3, pp. 584-587; MILLWARD, Peter. The Rebirth of the Football Fanzine. In Journal of Sport and Social Issues, 2008, Vol. 32, No. 3, pp. 299-300. 
their immediate response to stadium problems. In another sign of this activism, the period saw the establishment of the national Football Supporters' Association (FSA), which became both an organising platform for individual fan groups and a network for sharing information. Meanwhile, football zines provided a basic information forum for English, Welsh and Scottish fans.

Off the Ball was a nationwide zine that closely preceded When Saturday Comes. The first issue of When Saturday Comes appeared in 1986 in the form of 200 hand-stapled photocopies. The number soon increased, however, and by the mid1990s, the zine had been transformed into a national football monthly with a circulation of around 40,000 copies. ${ }^{29}$ One of the central motives for fanzine production in this period was the wish to describe and publicise the real problems of British football fans and thus provide some balance and a reality check for the largely negative image created by the British media. Unlike the fanzines put out by the fan communities of individual clubs, When Saturday Comes and Off the Ball were independent publications dealing with the concerns of football fans nationwide. As zine production expanded in the UK, more titles emerged across the entire football fan scene. By the mid-1990s, there were at least 400 active publications, and the total number of the zines, including those still existing and those already defunct, stood at around $600 .^{30}$

Jary, Bucke and Thorne highlight some of the key characteristics of British football fanzines between the 1970s and 1990s: 1) they were created by fans for fans; 2) although they were usually created by fans of one club for that club's supporters, they were independent of the club itself; 3) they opposed the control of football at the national level by commercial and media interests, including the promotion of the influence of the strongest clubs and TV interests; 4) where they were created by the fan groups of smaller clubs, they aimed to offset the media's focus on the most successful clubs from large cities; 5) they sought to combat misperceptions about the majority of football fans based on stereotypes in the media (including the social construct of the football hooligan, whose emphasis had led to the escalation of police control and a general deterioration of the stadium atmosphere) and 6) they expressed outrage at what they saw as an excessive police presence along with often pointless police offensives and security measures that restricted attendance and did little to enhance safety. ${ }^{31}$

Following this wave of British football fanzines, zines also began to appear in other European countries, with the first publications probably occurring in Italy. ${ }^{32}$ During the 1980s and 1990s, fanzines in the form of club and nationwide titles

29 GIULIANOTTI, Richard. Enlightening the North: Aberdeen Fanzines and Local Football Identity. In GIULIANOTTI, Richard - ARMSTRONG, Gary (eds.) Entering the Field: New Perspectives on World Football. Oxford : Berg, 1997, pp. 211-237.

30 BARBER, Gavin - WILLIAMS, John. Fact Sheet 7: Fan 'Power' and Democracy in Football, In Factsheets of Centre for the Sociology of Sport, University of Leicester, Department of Sociology, 2002, pp. 4-5. https://web. archive.org/web/20100821184842/http://www.le.ac.uk/so/css/resources/factsheets/fs7.html

31 In some cases, the critical stances of zine-makers sprang from their alienation from the attitudes of club management. The sale of some zines was forbidden in official club areas, and the creators were banned from stadiums. See JARY - HORNE - BUCKE 1991, pp. 585-587.

32 SHAW 1989, p. 14. 
emerged all over Europe. In reviewing fanzine journalism, it is often hard to distinguish independently produced fan magazines from commercially produced titles. Many of these foreign titles, in fact, began as independent zines produced by fans for fans but after a while were transformed into advertising revenue-generating publications that engaged semi-professional and professional journalists and photographers. At the same time, many of these titles marked a breakthrough in the non-commercial publication and fanzine scenes in their home countries at least in their initial phase.

In France, generally known for its strong fanzine production (especially in the realms of art and politics), football supporters published the fanzine/magazine SupMag, whose popularity peaked at 25,000 copies monthly between 1992 and $1995 .^{33}$ It was followed by titles such as Authentik Ultras, Culture Tribunes and Generation Ultras. The Italian magazine Supertifo was first published in 1985; fans and journalists initially contributed free content to the zine, which was later commercialised. A decade later, Fan's Magazine appeared on the national scene, including ultras in its target audience. Other Italian titles included the short-lived Hooligans, Ultra and Planeta TIFO. In Spain, Super Hincha magazine began publication in 1993 and for a time had a rival in El Jogador. The Portuguese fanzine Fanaticos was launched in 1993. It was followed by the Super Ultra zine, which had a significant influence on the fan movement despite only having a limited distribution of 1,000 copies per issue. Other publications from Portuguese fan communities included "Ultra, ... um modo de vida!" and Ultra Magazine, which later became Adeptos. The first football zine to appear in Germany, the then Czechoslovakia's neighbour, was Fan Tref in 1986. Subsequent titles included Match Live, Stadionwelt, Erlebniss Fussball and Blickfang Ultra, the latter two of which still exist today. In Hungary, the best-known nationwide title was 3. Félidö (The Third Half) while in Poland, the national zine Szalikowcy appeared in the 1990s. It was followed by the semi-professional zine/magazine To My Kibice (TMK), which has been around since 2001 and is one of the most influential of European fan magazines. An attempt was made to publish a Polish English-language magazine called Saturdays Heroes that would cover the entire European ultra scene. ${ }^{34}$ The Polish zines Szalikowcy and TMK have had a significant impact on the Czech fan scene.

According to Marchi, Roversi and Bruno, most French, German, Spanish and Portuguese football zines in the 1990s came from hooligan and ultra groups. ${ }^{35}$ This is probably due in part to the more compact nature and better organisation of these fan communities. It may also be surmised that there were certain key differences between the situation in continental Europe and the one in the UK, with the continental Europe group also including fanzine makers in Poland, Hungary, the former Czechoslovakia and the former Soviet republics. While the situation in these

33 DAUNCEY, Hugh - HARE, Geoff (eds.) France and the 1998 World Cup. The National Impact of a World Sporting Event. London : Routledge, 1999, p. 179.

34 For more details, see Historie nadklubových ultras fanzinů v Evropě in Hooligans.cz, 23. June 2013, http:// www.hooligans.cz/domains/hooligans.cz/index.php/books/2922-historie-nadklubovych-ultras-fanzinu-vevrope 35 Cited in GIULIANOTTI 1997, p. 232. 
countries is not entirely clear, it would seem that the national fan base was not sufficiently connected to form an association like the British FSA. In the absence of such an organisation, the tasks of this kind of information and organisational platform fell to successful local, national or transnational zines.

\section{Czech Football Zines}

In Czechoslovakia, the first official and semi-official publications to describe day-to-day events in the football world were the more or less amateur bulletins of individual sports and sports fan clubs. These clubs were established at various points after 1948, often in the guise of a Union of Friends of a particular club (this was the case, for example, with Slavia Prague, Baník Ostrava and Sparta Prague). With few exceptions, these bulletins provided little coverage of events in the stands and behind-the-scenes developments. ${ }^{36}$ Fans therefore obtained information about the game mainly from critical reports in the official media, which, as a rule, only focused on occurrences in the stands in the event of some social disturbance. These reports reflected the general image of the violent and uninhibited behaviour of certain fan groups held by "decent" fans and the majority of society. And they expressed society's condemnation. In many cases, they also pointed to a clash between the generations: many in the older generation had not taken well to changes in the traditionally shared stand areas when new patterns of behaviour began to spread among fan groups in the 1980s. Given the gap in the official coverage, it was only logical that a need arose for spaces where information about the fan scene (including its semi-legal and illicit aspects) could be exchanged. This was driven - entirely in the spirit of the laws of supply and demand - by the interests of both highly active fans and more general spectators.

While football zines were not included in the first major critical survey of fanzines in the former Czechoslovakia, ${ }^{37}$ the converse was true in international historiography and social science research. Internationally, football zines were often cited as a historical source, and several studies dealt with them as a specific phenomenon. This was mainly due to the greater number of subculture scenes, including football fan communities, in places like the United Kingdom, but it also reflected the longer tradition and greater number of alternative media outlets in the English-speaking world generally. In the Czech Republic, as we have seen, the rise in the independent media of football fans was around ten years behind the British wave and did not occur until the first half of the 1990s. The reason for this lay partly in the continuing political restrictions on the cross-border movement of people and information from socialist Czechoslovakia despite some reforms in the second half of the 1980s. Independent media production before 1989 was also limited

36 Spartaklub, the magazine of Sparta club fans, included an early version of modern-style "reports" on the attendance of individual matches as far back as the 1960s. The magazine was published by the Union of Friends of Sparta (originally called Spartaklub). See Střípky minulosti, aneb se Spartaklubem do historie I. In SpartaForever.cz, 27. January 2012, https://www.spartaforever.cz/ukaz_clanek.php?clanek=2317

37 HROCH, Miloš. Křičím: "To jsem já": příběhy českého fanzinu od 80. let po současnost / I Shout "That's Me!": Stories of the Czech Fanzine from the '80s Till Now. Praha : PageFive, 2017. 
by the lack of access to mass printing technology and its control by the state as well as the potential criminalisation of the publication of "harmful" material. As a result, there was generally no growth of independent media until the liberalisation measures after 1989. Open borders brought the virtual free movement of information and cultural exchange, and this was accompanied by commercial printing options and the relatively unrestricted freedom of speech.

Considered the first Czech football fanzine, Bazal, which continues to be published today by members of the Baník Ostrava fan scene. The first issue appeared in August 1991 and was meant as an occasional publication from FC Baník Ostrava OKD Fan Club. It featured information about, among other things, fans' trips and football tournaments and the establishment of FC Baník Fan Club, which replaced the club's former Union of Friends. Over time and thanks to growing opportunities, Bazal saw changes in both its content and appearance. As the oldest continuously published fan title, it also eventually obtained its own banner, which reads "The oldest zine of the best fans". Bazal's 100th issue inspired a special choreographed routine by Baník Ostrava supporters during their trip to Zlín. Since 2016, the zine has appeared in colour with extended content, ${ }^{38}$ and in 2019 it saw its 156 th issue. In the 1990s, similar titles could be found on the scene, but none have survived or been published for as long as Bazal. This zine is thus a real phenomenon in Czech independent fan journalism.

Beginning in the 1990s, several other football fan communities released their own zines. This rise in Czech publications was not connected with any external attacks, as had been the case, for example, with the growth of the UK football zine scene and birth of the FSA. Rather, as we have seen, the Czech output was more likely linked to the opening of the state borders, which enabled cultural exchange. This meant not only the emulation of foreign styles but also other effects of the mingling and clashing of subcultures, including the copying of communication conventions within and across individual scenes. In a very real way, all of this was aided by the end of the state's preliminary censorship of periodicals and a substantial decrease in control and sanctions around content compared with the pre-1989 situation. In terms of both their substance and publication standpoint, Czech and Slovak football fanzines focused more on hooligans and ultras, a slant similar to the one seen in Germany and Italy. ${ }^{39}$ In most cases, each title published dozens of issues (with only rare instances of hundreds of copies), and the Czech publications fell decisively short of the distribution of similar alternative outlets abroad. At the turn of the millennium, the Czech zines thus reflected the general features of classic fanzines: they were non-commercial, essentially amateur publications created by members of a subculture group for that group. They cannot be conceived of as a large-scale phenomenon comparable to the football zines that hit the UK in the 1980s. Aside from their links with the German scene, Czech hooligan and ultra subcultures are most closely related to the Polish and Hungarian scenes, and zines from Poland and Hungary continue to show up often in the Czech environment.

38 For more information, see Bazal - recenze na poslední čísla. In Chachari.cz, 5. January 2019, http://www. chachari.cz/bazal-recenze-na-posledni-cisla-rn2087

39 GIULIANOTTI 1997, p. 232. 
As of 2004, Czech football clubs were linked to the following fanzines published by groups in their hooligan and ultra scene: 1. FC Brno - Eagle (publisher: Johny Kentus Gang) and Orthodox (publisher: Orthodox Fans Brno); České Budějovice - Gauner (publisher: Brigade Gauners); Hradec Králové - United Vandals (publisher: Regiment Königgratz); FK Jablonec - Gablonz Supporters (publisher: Corps Juniors); Sigma Olomouc - Dvě stránky (published by fans of Sigma Olomouc); Silesian FC Opava - Bulldog Corps (publisher: Bulldog Corps); Baník Ostrava - Bazal (published by fans of Baník Ostrava) and Chachar Boys (publisher: Chachar Boys); Bohemians Prague - Lalášek (publisher: Berserk); Slavia Prague - Fanatik (publisher: Brigate '97), Time for You (publisher: Slavia Hooligans) and Výtržník (publisher: Slavia Youngsters); Sparta Prague - Ultras (publisher: Brigade Drápek z Lasičky), Bezmozek Times and Pirát (publisher: Red Pirates Sparta); Viktoria Pilsen - Alcohools, Wolwes and Blue Red Wolves Pilsen (publisher: Blue Red Wolves Pilsen), Pilsen Fans (publisher: Pilsen Fans) and Pilsen bOils informátor (publisher: Pilsen bOils ).$^{40} \mathrm{~A}$ complete list of major documented zine titles, including their publisher and known time frame, is attached to this article as Annex 1. Documented zines come mainly from the scenes of the largest fan groups and therefore tend to be associated with first-league football clubs.

In total, there have been about 40 football zines published in the Czech or Slovak Republics (around 30 in the CR and around 10 in the SR) at different times. Compared to the UK scene, this number is relatively small, but it reflects certain key features of the local environment. These include the relatively fragmented interests of the fan (hooligan) groups that have tried to influence both the negative image of the fan community in the mainstream media and the policies of the official football establishment (especially the Football Association of the Czech Republic). Most Czech football zines have focused entirely on the history and specifics of individual clubs, or more precisely, their hooligan and ultra scenes. Thus, information about the scene has often been based on highly subjective experiences and attitudes. There have, in fact, been only two titles which have aspired to a more nationwide outlook and information about the hooligan and ultra scene. The first of these is Vlajkonoši, whose editorial team was made up of Sparta Prague hooligans. And the second is Football Factory, a landmark publication and the first enduring national zine. ${ }^{41}$

\section{Football Factory and the Decade of the Czech Nationwide Zine}

The first issue of Football Factory came out in July 1998 and, together with a brief introduction to hooligan groups from Ostrava, Sparta Prague and Hradec Králové, featured information about fan trips, some interesting facts about foreign scenes, photos of the Kops and clips from the mainstream press. The zine's publisher, who appeared in its pages under the pseudonym Č.N.L., has since said that he was involved in publishing Bazal but drew inspiration for a nationwide zine from the Polish

40 This list represents titles documented by researchers focusing on the hooligan scene. See MAREŠ - SMOLÍK SUCHÁNEK 2004, p. 135-137; SMOLÍK 2008, p. 270.

41 The zine's title came from the 1988 novel The Football Factory by debut British author John King, which was set in the hooligan scene around London-based club Chelsea. King followed the book with two sequels, Headhunters (1997) and England Away (1998). In 2004, a film version of The Football Factory was released under the same name. 
title Szalikowcy. The initial print run of Football Factory was only around 150 copies but it reached its peak in 2004 at about 700 copies. Later, with the rise of the Internet, this number fell to between 500 and 550 copies. According to the publisher, he initially relied on the mail to connect with individual contributors and readers. He also confirms that internal problems in the domestic scene led to its fragmentation and that these were not limited to the late 1990s. Among the problems were the fairly tense relationships among the fan groups of individual clubs, which often lacked any capacity for a detached view. These tensions also affected efforts to capture an objective view of the hooligan and ultra scene in the Czech Republic and led to boycotts of Football Factory by some groups. ${ }^{42}$

The original version of Football Factory appeared between 1998 and 2008. The first issue, as we have noted, came out in July 1998 and the last (60th) edition was part of volume 11 in August 2008. While in the early years, the zine had a maximum of 40 pages, the content almost doubled in the final years. Despite its relatively long existence, the basic design features barely changed: Football Factory had a colour front cover and two-sided back cover. The rest of the content was black-and-white except for a colour insert originally comprising two and later three pages. From the second year onwards, unauthorised copies of Football Factory began to appear as a result of its price (which was meant to cover overheads). The publisher responded by placing a note in the zine that read: "The original edition has a colour cover and centrefold." The main change to the zine's graphics consisted of the replacement of the simple football club logos that accompanied texts with black-and-white photo illustrations. At the same time, the publication began to include more elaborate advertising, the volume of which grew over time. Nevertheless, when compared to other fanzines of the period, Football Factory maintained a relatively conservative look throughout the decade. It also increased its distribution network: the zine was available to subscribers and, as of 2004, could also be bought at seven different outlets - two in Prague, two in Ostrava and one in each of Brno, Pilsen and České Budějovice. The final issue could be purchased at 13 locations (four in Prague, two in Ostrava and one in each of Brno, Pilsen, České Budějovice, Liberec, Tanvald, Uherské Hradiště and Bratislava, Slovakia). The distribution points were shops devoted to subculture fashion and football fan merchandise. ${ }^{44}$

In terms of its content, Football Factory only saw limited changes in response to specific developments in the non-mainstream football fan scene. The zine remained concerned with the everyday lives of football hooligan and ultra groups. Most of the content consisted of reports of individual matches and related events such as the creation of choreographies and to their status in the ultra scene, more or less pre-arranged clashes between hooligan groups and domestic and international alliances. The co-

42 These comments by Football Factory's publisher, Vladimír Novák (here called by the nickname "Ženklavák") appeared in a 2013 interview. See Rozhovor s ČNL - vydavatelem zinu Football Factory. In Supporters.cz, 12. May 2013; https://www.supporters.cz/clanek/rozhovor-s-cnl-vydavatelem-zinu-football-factory/4935.html. Vladimír Novák was named in the print edition of Football Factory as its editor-in-chief and publisher from the publication of volume 7 in 2004.

43 Upozornění. In Football Factory, 1999, Vol. 2, No.4, p. 39.

44 Kde FF koupíte? In Football Factory, 2004, Vol. 7, No. 29, p. 3; Kde FF koupíte? In Football Factory, 2008, Vol. 11, No. 60, p. 3 . 
verage included not only the domestic scene but also the national football team and, to some degree, events in neighbouring countries. Compared to other hooligan and ultra publications, Football Factory was ground-breaking in its effort to record the scene not from the perspective of one particular group but by providing a space for different views; this was especially true in the case of conflicts between competing gangs, where assessments by individual club zines tended to be highly subjective. In the context of the radical fan scene, the zine's breakthrough status lay, among other things, in its relative availability and provision of information to scene insiders, uninvolved fans and eventually also critical commentators. ${ }^{45}$

Match reports were accompanied by information about the hooligan and ultra groups in individual local clubs, ratings of trips and portraits of groups and scenes in the United Kingdom, France, Poland, Italy, Germany and elsewhere internationally. The zine also highlighted information about the football hooligan and radical fan subcultures that had appeared in the mainstream media and thus showed the media's image of both the international and domestic scenes. And there was content from other Czech and international fanzines. Moreover, Football Factory connected the Czech hooligan and ultra scene in a way that allowed for the sharing of other kinds of information, including growing advertising of goods, especially hooligan fashion and fan accessories and other fanzines. Regular features included surveys about issues in the fan scene (e.g. the place of politics in the stands, racism, pre-arranged clashes among unarmed fans, a potential truce during matches of the Czech national team etc.), reader feedback, commentary on scene developments and reviews of mainstream cultural products about the issues of football hooligans or ultras. ${ }^{46}$

Football Factory covered a relatively distinct decade (1998 - 2008) that saw the transformation of subculture scenes and their communication platforms. These changes were based, in part, on a generational change, as increasing numbers of active members of the 1990s ultra and hooligan scenes cut back their activities. At the same time, it reflected the massive development of the Internet just before and after 2000. Online communication allowed a new generation to share information more flexibly and provided greater possibilities for anonymity when communicating about events that often existed in a legal grey area. After 2000, links to websites dedicated to hooligans and ultras slowly began to appear in Football Factory. These included the Polish sites kibice.pl, chuligani.prv.pl and tomykibice.com and the Czech site www.hooligans.cz. The latter has been in operation since 1999, changing owners for the first time in 2004 and again after

45 Even before it ceased publication, Football Factory featured in critical analyses of the hooligan and ultra scene as one of the key communication platforms of its era. For a qualitative content analysis of several issues, see VOCHOCOVÁ, Lenka. Třetí poločas - fotbaloví chuligáni v CR a násilí. In Rexter, 2007, Vol. 2, pp. $1-37$.

46 This commentary included, for instance, a discussion of the film Non plus ultras, which was then in production. At the time, it had been announced that the film would focus on the issues of football fans in the Czech Republic. In fact, it only touched on the topic marginally with the hooligan scene serving more as a backdrop for the comedy. See $V$ současnosti se u nás pod názvem „non plus ultras natáčí nový film o životě fans. In Football Factory, 2003, Vol. 6, No. 22, p. 48. 
2007. The website gradually became more professional, and in 2008 it recorded almost two million visitors annually. ${ }^{47}$ As we have seen, with the rise of the Internet, there was a drop in the number of copies of the Football Factory zine.

As the scene went from physical to virtual, many traditional fanzines did not survive the shift. These same pressures were at work in the UK football fan environment where there has been, however, increased commodification of the once marginalised football hooligan and ultra scenes since the $1990 \mathrm{~s}^{48}$ Some UK fanzine titles also transitioned to virtual form. It is symptomatic that British social scientists are at least ten years ahead in addressing these changes as part of their work on football fans and the materials that illuminate their daily lives. ${ }^{49}$ Meanwhile, in the Czech context, it appeared at first that Football Factory might be among the many fanzines that could not overcome the advent of new media. The zine published its last issue in 2008. The publisher retained the domain name www.footballfactory.cz but used the site to support the sale of fan merchandise while yielding the task of informing the scene to the already established Hooligans.cz. Other information sites followed, including some focused on individual clubs and other super club sites committed to the broader scene. An analysis of the organisational transformation of the Czech hooligan and ultra scene is beyond the remit of this study. Nevertheless, it can be assumed that contributing factors have included heavier regulation by repressive authorities, generational shifts within individual groups, changes to the rules on inter-group conflicts (affecting whether they are pre-arranged, in a pre-selected place, unarmed, etc.) and the rise of social media networks, which in many respects have replaced earlier and often more personal ties.

\section{Football Factory's Legacy and the Revival of Football Fanzines?}

Like many other (sub-)cultural products, Football Factory has been the target of a recent trend that might be called resurrection or return from the Internet to the physical world. ${ }^{50}$ In 2019, 11 years after the last issue of the original zine, the print title was revived by a new editorial team and publisher. ${ }^{51}$ In 2019 , five issues were published, and while it remains to be seen how it will survive the current virtual era, both the demand and nostalgia for the publication have been evident

47 Historie webu hooligans.cz. In Hooligans.cz, 11. July 2015, http://www.hooligans.cz/index.php/reports/ czech/4743-historie-webu-hooligans-cz-99-2015

48 An analysis of the commercialisation and commodification of the radical fan scene goes beyond the scope of this study. It is worth noting, however, that since 2000, there has been a growing supply of stories from the hooligan scene, particularly in the UK. These narratives include the memoirs of leading hooligan gang personalities (for example, Cass Pennant) and movies like The Football Factory (2004), Green Street Hooligans (2005) and Cass (2008). The Czech film industry responded with Non Plus Ultras (2004) and Horem pádem (2004), however both these productions featured the football fan scene as more of a backdrop. The lack of memoirs by Czech football hooligans of the late 1980s and early 1990s is symptomatic of the relatively small size of the local scene. As such, there is far more limited potential for commercialisation and commodification.

49 See MILLWARD 2008, pp. 299-310.

50 For more information about zines in the Internet age, see HROCH, Miloš. Samizdat v informační době: Jak ovlivnil Web 2.0 kulturu fanzinů. Diplomová práce. Praha : Fakulta sociálních věd UK, 2016.

51 The print edition lists its publisher as Jan Lysáček while the editor-in-chief is Petr "Proktor" Hrdlica. See the imprint in Football Factory, 2019, No 2, p. 3. 
on hooligan and ultra-themed sites for some time. In the first issue, the team behind the new Football Factory summarised with some sentimentality the years that had elapsed since the shutting down of the original version. From a design perspective, the quality of the new iteration is of an altogether different level to the original Football Factory, which is understandable when we take into account technological innovations. From the point of view of content, however, the magazine strives to keep its original format.

The lifespan of Czech football zines has proven to be quite a vexed issue. As far as club-zines are concerned, Bazal preserves its long tradition, but many other independent publications have had relatively short lives. Most zines of earlier eras found themselves unable to survive the advent of new forms of online information-sharing, including the transformation brought about by the new web form of blogs. New information websites emerged in the online space, linking up Czech ultra and hooligan communities far more effectively than traditional print media had done. At the national level, key sites included Hooligans.cz and later Supporters.cz, and there are also several sites focused on local issues for individual clubs or groups. After 2000, the Internet meant, on the one hand, the accelerated sharing of information and, on the other new means to police its content and distribution. As time went on, discussions of football ultras and hooligan gangs began to appear on social media.

Aside from the "Internet turn", several other factors contributed to the decline of football zine journalism. Clearly, one was the generational change, with new forms of communication replacing older ones that were deemed ineffective by younger fans because they did not allow for dynamic sharing or the immediate expression of opinions via personal preferences. A second reason lay in the relatively limited reach of the Czech ultra and hooligan scene, not only in terms of individual groups but also in terms of its wider "audience". Additional factors may be the relative fragmentation of the Czech fan scene and the somewhat short-sighted economic priorities of national football association and the media, which contribute little to supporting football fan communities.

In terms of their direct impact, Czech football fanzines were the products of a limited scene and a limited trend. As such, they remained quite marginal from the standpoint of overall Czech fanzine production and, to some extent, their influence on the fan community. Nevertheless, they represent a historical source that is in many ways unique, recording not only the evolution of the Czech hooligan and ultra scene and its members' daily lives but other related social issues. With few exceptions, the zines dedicated to the individual hooligan or ultra group of a particular club did not survive the rise of new media. And while an effort has been made to revive the once formative Czech super-club football zine Football Facto$r y$, it remains to be seen whether it will find a stable readership in the context of ever-transforming virtual media. 
Annex 1 .

\begin{tabular}{|c|c|c|c|}
\hline Title & Year & Author/publisher & Note/subtitle \\
\hline \multicolumn{4}{|c|}{ Czech Republic } \\
\hline Alcohools & 1990s & $\begin{array}{l}\text { Pilsen Fans (Pilsen football and } \\
\text { ice hockey fans) }\end{array}$ & \\
\hline Bazal & $\begin{array}{l}1991-2019 \\
\text { (no. } 156-2019)\end{array}$ & Fan club of Baník Ostrava & \\
\hline Berserk & since 1999 & $\begin{array}{l}\text { Berserk (Bohemians Prague hoo- } \\
\text { ligans) }\end{array}$ & $\begin{array}{l}\text { Irregular periodical for Bohemi- } \\
\text { ans, Slavia and Pardubice fanatics }\end{array}$ \\
\hline Bezmozek Times & 1990s & AC Sparta hooligans & Only for hooligans \\
\hline $\begin{array}{l}\text { Blue Red Wolves } \\
\text { Pilsen }\end{array}$ & 2000 & Viktoria Plzeň fans & \\
\hline Bohemák & since $2004-2006$ & Bohemians Prague fans & \\
\hline $\begin{array}{l}\text { Bulldog Corps } \\
\text { News }\end{array}$ & since 1998 & $\begin{array}{l}\text { Hooligans SFC Opava (Bulldog } \\
\text { Corps) }\end{array}$ & $\begin{array}{l}\text { Informational zine of supporters } \\
\text { of SFC Opava }\end{array}$ \\
\hline Cadalso del Sur & 2005 & $\begin{array}{l}\text { SK Slavia Prague fans } \\
\text { (Jiří Vojáček?) }\end{array}$ & $\begin{array}{l}\text { Fanzine of supporters of SK Sla- } \\
\text { via Prague }\end{array}$ \\
\hline Dvě stránky & 1998 & Sigma Olomouc fans & $\begin{array}{l}\text { Not only for die-hard fans of Sig- } \\
\text { ma Olomouc, originally in the } \\
\text { character of a bulletin }\end{array}$ \\
\hline Eagle & $\begin{array}{l}\text { since the season } \\
1998 / 1999-\text { at } \\
\text { least until } 2002\end{array}$ & $\begin{array}{l}\text { Johny Kentus Gang (FC Brno } \\
\text { hooligans) }\end{array}$ & \\
\hline Fanatik & & $\begin{array}{l}\text { SK Slavia Prague Hools } \\
\text { (Brigate ‘97) }\end{array}$ & Irregular periodical of Slavia fans \\
\hline Fan Klub Vítek & since 1990 & TJ Vitkovice fans & \\
\hline Football Factory & $\begin{array}{l}1998-2008 \text {, } \\
\text { revival } 2019 \text { (first } \\
\text { four issues under } \\
\text { different editorial } \\
\text { team) }\end{array}$ & $\begin{array}{l}\text { Č.N.L. - Ženklavák (Vladimír } \\
\text { Novák), contributors from all over } \\
\text { the Czech Republic }\end{array}$ & $\begin{array}{l}\text { Now legendary nation-wide fan- } \\
\text { zine which drew inspiration from } \\
\text { foreign zines. }\end{array}$ \\
\hline Football Madness & 1990s & FC Zlín hooligans & \\
\hline $\begin{array}{l}\text { Gablonz Support- } \\
\text { ers }\end{array}$ & 2000 & $\begin{array}{l}\text { Jablonec nad Nisou ultras and } \\
\text { hooligans }\end{array}$ & $\begin{array}{l}\text { Irregular periodical of Jablonec } \\
\text { hools and ultras. }\end{array}$ \\
\hline Gauner & since 2000 & $\begin{array}{l}\text { Brigade Gauner Budweiss (Dyna- } \\
\text { mo České Budějovice) }\end{array}$ & Irregular periodical of the fan club \\
\hline Hooligans & & FC Zlín hooligans & Nepravidelný zlínský zin \\
\hline Hooligans & 1996 & Slavia Prague fans & Special issue of the zine Výtržník \\
\hline Chachar Boys & $1996-1999$ & Baník Ostrava hooligans & $\begin{array}{l}\text { Irregular periodical of Ostrava } \\
\text { hooligans. Articles on Baník Os- } \\
\text { trava, GKS Katowice, Czech Re- } \\
\text { public }\end{array}$ \\
\hline Lalášek & $\begin{array}{l}\text { since the season } \\
1999 / 2000\end{array}$ & $\begin{array}{l}\text { HC Pardubice and Bohemians } \\
\text { fans }\end{array}$ & Pardubice-Bohemians zine \\
\hline Orthodox & since 1998 & Orthodox Fans Brno & $\begin{array}{l}\text { Information on developments } \\
\text { concerning the FC Brno fan scene }\end{array}$ \\
\hline $\begin{array}{l}\text { Pilsen Boils In- } \\
\text { formátor }\end{array}$ & since 2000 & Pilsen Boi!S & \\
\hline Pilsen Fans & & $\begin{array}{l}\text { Viktoria Plzeň and HC Plzeň fans } \\
\text { fanzine }\end{array}$ & \\
\hline Pirát & $1998-2000$ & Red Pirates Sparta & $\begin{array}{l}\text { Bulletin of the club Red Pirates } \\
\text { Sparta }\end{array}$ \\
\hline
\end{tabular}




\begin{tabular}{|c|c|c|c|}
\hline Slezan & since 1999 & SFC Opava fans & $\begin{array}{l}\text { Fanzine of the warriors from Sile- } \\
\text { sian capitals (SFC Opava, WKS } \\
\text { Śląsk Wrocław) }\end{array}$ \\
\hline Stupid & & Sparta Prague fans & \\
\hline Time for You & since 2000 & Slavia Hooligans & \\
\hline Ultrafans & & Slavia Prague Fans (Fanatics) & \\
\hline Ultras Sparta & since $1997-1998$ & $\begin{array}{l}\text { Brigade Drápek z Lasičky (AC } \\
\text { Sparta hooligans) }\end{array}$ & \\
\hline United Vandals & 1990s (?) & $\begin{array}{l}\text { Regiment Königgratz (SK/FC } \\
\text { Hradec Králové) }\end{array}$ & \\
\hline Vlajkonoši & since 2000 & $\begin{array}{l}\text { editorial team - AC Sparta hoo- } \\
\text { ligans }\end{array}$ & National zine \\
\hline Výtržník & 1990s (1998) & $\begin{array}{l}\text { Slavia Prague fans (Slavia Young- } \\
\text { sters) }\end{array}$ & \\
\hline Wolves & & Viktoria Plzeň fans & \\
\hline \multicolumn{4}{|c|}{ Slovak Republic } \\
\hline Bulldog & & Bulldog 95 (Nitra) & $\begin{array}{l}\text { Irregular periodical of the fan club } \\
\text { FC Nitra }\end{array}$ \\
\hline Dukla & since 2002 & Dukla fans Banská Bystrica & $\begin{array}{l}\text { Fanzine of Dukla fans Banská By- } \\
\text { strica }\end{array}$ \\
\hline $\begin{array}{l}\text { Futbal je len } \\
\text { zámienka }\end{array}$ & $1990 s$ & ŠK Slovan Bratislava fans & $\begin{array}{l}\text { Irregular periodical of thickhead- } \\
\text { ed, demented aggressors, hoo- } \\
\text { ligans and fans and supporters } \\
\text { of ŠK Slovan }\end{array}$ \\
\hline Made in Košice & since $1998-2001$ & fan club of 1. FC Košice & $\begin{array}{l}\text { Irregular periodical of the fan club } \\
\text { 1. FC Košice }\end{array}$ \\
\hline No Name & since 1997 & Belasí fanatici (Slovan Bratislava) & \\
\hline Red Black Warriors & $1998-2000$ & Spartak Trnava fans & $\begin{array}{l}\text { Magazine of the fans of the Trnava } \\
\text { football }\end{array}$ \\
\hline R.W.A. & since 2003 & $\begin{array}{l}\text { Red White Angels (Dukla Banská } \\
\text { Bystrica) }\end{array}$ & \\
\hline Supporters & since 1999 & $\begin{array}{l}\text { Psycho boys } 98 \text { (1. FC Košice } \\
\text { hooligans) }\end{array}$ & \\
\hline Vanguard & since 2004 & $\begin{array}{l}\text { Dukla Banská Bystrica support- } \\
\text { ers }\end{array}$ & \\
\hline Warrior & since 2004 & $\begin{array}{l}\text { Red-Black Warriors (Spartak Tr- } \\
\text { nava) }\end{array}$ & \\
\hline Život fanatika & & $\begin{array}{l}\text { Concordia } 1906 \text { MFK Ružomber- } \\
\text { ok }\end{array}$ & \\
\hline
\end{tabular}

Cituj:

LOMÍČEK, Jan. On Football Fanzines: A Communication Platform for Czech and Other European Football Fans. In Forum Historiae, 2020, Vol. 14, No. 1, s. 120-139. ISSN 1337-6861. DOI: https://doi. org/10.31577/forhist.2020.14.1.9

Jan Lomíček

Odělení dějin tělesné výchovy a sportu

Národní muzeum

Vinohradská 1

11000 Praha 1, Česká republika

E-mail: jan.lomicek@nm.cz 